\title{
GOLIDEN CALF OR HOLY COW? ANIMALS AND THE SACRED
}

\section{Reverend Gary Kowalski} Boulder, Colorado

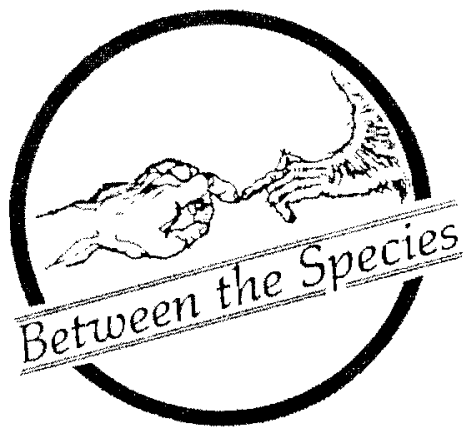

Above the first edition of his book Daniel, Martin Buber inscribed the words of the medieval theologian Scotus Eriugena: Deus in creature mirabili et ineffabili modo creatur. "In a wonderful and inexpressible way God is created in his creatures."

Animals were sacred to the Jewish thinker. It was through his rapport with a horse he befriended on a visit to his grandfather's country estate when he was eleven years old that Buber first awakened to "the immense otherness of the Other."

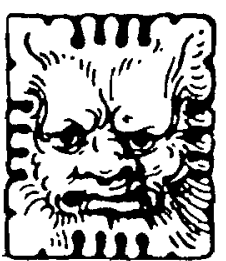

RELIGION

Jim Harter, Animals: 1419

Copyright-Free Illustrations.

New York: Dover, 1979 
When I stroked the mighty mane, sometimes marvellously smooth-combed, at other times just as astonishingly wild, and felt the life beneath my hand, it was as though the element of vitality itself bordered on my skin, something that was not 1 , was certainly not akin to me, palpably the other, not just another, really the Other itself; and yet it let me approach, confided itself to me, placed itself elementally in the relation of Thou and Thou with me. The horse, even when I had not begun by pouring oats for him into the manger, very gently raised his massive head, ears flicking, then snorted quietly, as a conspirator gives a signal meant to be recognizable only by his fellow conspirator: and I was approved.

Such experiences are not uncommon. For many children, even today, it is an animal who first introduces them to the mysteries of birth and death, and invites them to ponder what it means to be alive. Buber was unusual, perhaps, in never allowing the years to dim that youthful awareness of the mysterium that resides in other living beings. A creature as domestic and seemingly mundane as a house cat remained a wild and unfathomed Thou. "The eyes of an animal have the capacity of a great language," Buber testified, and the cat's glance for him bore a question: "Can it be that you mean me? Do you actually want that I should not merely do tricks for you? Do I concern you? Am I there for you?" This instant of communication with another specie, though fleeting, left a powerful impression. As Buber wrote in I and Thou, "No other event has made me so deeply aware of the evanescent actuality in all relationships to other beings..." Such holy encounters with animals, as well as with trees and stones, were spiritually formative. His biographer Maurice Friedman writes that "Buber's experience of inclusion in relation to nature is perhaps the most consistent thread in his entire philosophy."

If theology begins with the question, "Where in our experience do we locate the sacred?", we must acknowledge that many people discover it in and through other living creatures. Nature mysticism direct communion with the Holy present in bird, beast, and forest - may be the oldest and most universal mode of human religiosity. In the high mountain caves of Germany and Switzerland, Old
Stone Age implements lie side by side with the skulls of cave bears that appear to have been arranged into symbolic patterns, remains which most scholars interpret as evidence of a cult of bear veneration which existed among the Neanderthals who inhabited the region 70,000 years ago. Fifty thousand years later, the people of what is now Lascaux, France, created the world's first religious art as they decorated the ceilings of their caves with magnificent images of bison, black stag, ibex and arctic pony. While it is impossible to reconstruct the sacred cosmos of our human and proto-human ancestors, it may have had aspects in common with the thought world of people like the American Indians, who preserved a similar hunting-andgathering existence into modern times. "In the beginning of all things," said the Pawnee Chief Letakots-Lesa at the turn of the century, "wisdom and knowledge were with the animals; for Tirawa, the One Above, did not speak directly to man. He sent certain animals to tell men that he showed himself through the beasts, and that from them, and from the stars and the sun and the moon, man should learn." For such people, the creatures of the earth naturally possessed sacred significance.

\section{The dominant stream of religious reflection in our culture has erected an antithesis between divine nature and animal nature, so that the god-like has been contrasted with the bestial and the heavenly countered to the earthly.}

In contrast, the religions of the West have been anthropocentric in focus. The statement that "human life is sacred" would probably find ready assent among most Jews and Christians, for instance, but the proposition that the life of a salmon or 
porcupine is sacred presents a more problematic claim. The dominant stream of religious reflection in our culture has erected an antithesis between divine nature and animal nature, so that the god-like has been contrasted with the bestial and the heavenly countered to the earthly. To approach God, for human beings, has meant to suppress or transcend what one has in common with other living creatures.

This polarity begins in the Bible. In the eighth psalm, we read:

What is man that You are mindful of him,

And the son of man that You visit him?

For You have made him a little lower than the angels,

And You have crowned him with glory and honor.

You have made him to have dominion over the works of Your hands;

You have put all things under his feet,

All sheep and oxen -

Even the beasts of the field,

The birds of the air,

And the fish of the sea

That pass through the paths of the seas.

Human beings alone resemble God, in this vision, and this resemblance sets them over and apart from all other animals. The God of Israel is not only an anthropomorphic deity who creates men and women in his own image, he is also an historical deity, who, as the prophets never tired of reminding their listeners, should not be confused with the nature gods of the Canaanites. The episode of the golden calf, whatever its historical accuracy, reveals Israel's profound and pervasive hostility toward representing the divine in non-human form.

Christian theology inherited this human-centered bias, and was equally influenced by the philosophers of Greece. Aristotle, in his treatise On the Soul, distinguishes three grades of soul. To plants he assigns a "vegetative soul" which enables them to carry out the basic operations of nutrition, growth and reproduction that they share with all living beings. Animals possess, in addition, a "sensitive soul" which animates their bodies and endows them with feeling. Of all animals, only human beings have a soul that permits them to think and reason.
Therefore, Aristotle states in On the Parts of Animals, "of all living beings with which we are acquainted man alone partakes of the divine, or at any rate partakes of it in a fuller measure than the rest."

Christian theologians adopted this conclusion. Augustine also distinguishes "three grades of soul in universal nature," and in On Christian Doctrine declares that "a great thing truly is man, made after the image and similitude of God, not as respects the mortal body in which he is clothed, but as respects the rational soul by which he is exalted in honor above the beasts." Aquinas was able to discern five varieties of soul - vegetative, sensitive, appetitive, locomotive and intellectual - but likewise agreed that "Man is said to be after the image of God not as regards his body, but as regards that whereby he excels other animals ... Now man excels all animals by his reason and intelligence. Hence it is according to his intelligence and reason, which are incorporeal, that man is said to be according to the image of God" (Summa Theologica, First Part, Question 3, Article I, "Whether God Is a Body?").

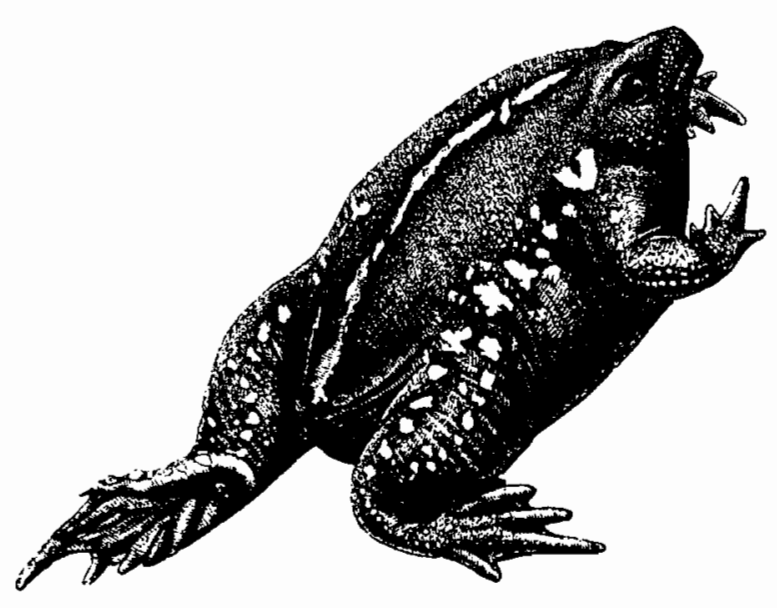

Carol Belanger Grafton, Old-Fashioned Animal Cuts. New York: Dover, 1987 
The basic Aristotelian assumption that thinking puts human beings above the beasts and "on the side of the angels" is never questioned. But it might be asked, why is a being who produces thoughts and ideas nearer to God than another being that happens to produce flowers, or another that generates birdsong? After all, we admire other animals for their beauty, aliveness, wildness and innocence. They play and sport, they care for their young, and are capable of loyalty, affection, and altruism. They have qualities which, whatever their intelligence or lack of it, might be thought to entitle them, along with humans, to the claim of being stamped with a divine impress. Why, then, is what Aristotle called "the rational principle" the only trait worthy of this honor?

\section{Animal liberation, which at its heart is a call for a shift from an ego-centered to an eco-centered spirituality, also implies human liberation, for it frees us from an idolatrous concept of God.}

Though it sounds absurd, the answer is that "higher" is "better." In Aristotle's cosmology, the celestial realm is one of perfect form and unchanging motion, while our sub-lunary sphere is subject to imperfection, irregularity, and decay. Through reason, human beings can contemplate the upper regions of unsullied and immutable truth, where the First Heaven engages in the pure noetic bliss of "thought thinking about thinking." Since the heavenly is literally higher than the earthly, in a spatial as well as a normative sense, man actually "stands above" the other animals, not only in height but in rank. "For of all animals man alone stands erect, in accordance with his god-like nature and essence," writes Aristotle in On the Parts of Animals. "For it is the function of the god-like to think and be wise; and no easy task were this under the burden of a heavy body, pressing down from above and obstructing by its weight the motions of the intellect and of the general sense." All other animals are dwarf-like in form, the philosopher maintains, and like human dwarves or infants that crawl upon the ground, have a larger admixture of "earthy matter" in their constitutions and less of "elevating heat," rendering them naturally inferior to those with an upright posture. While plants might appear to grow upwards, and thereby contradict the generalization that altitude automatically enobles, Aristotle explains that plants in fact grow upside down their roots correspond to the heads of animals, since this is where their nutritive organs are located and so they only serve to prove the rule. In short, Aristotle places human beings nearest to God because they, of all creatures, have their heads in the clouds.

These peculiar theological notions greatly influenced Christian thinkers. Augustine asserts in the City of God that "Man has not been created stooping towards the earth, like the irrational animals; but his bodily form, erect and looking heavenwards, admonishes him to mind the things that are above," and Aquinas, in addressing the question "Whether the Body of Man Was Given a Fitting Disposition?" (Summa Theologica, First Part Question 91, Article 3) concurs. The Aristotelian worldview so thoroughly infiltrated the thinking of the Church Fathers and theologians of the Middle Ages that by the time of the Reformation it had become a reflexive habit of mind. Thus John Calvin, in his Institutes of the Christian Religion (Book I, Chapter XV) would quote with approval the verses of Ovid:

While the mute creation downward bend

Their sight, and to their earthly mother tend,

Man looks aloft, and with erected eyes,

Beholds his own hereditary skies.

Meanwhile, on a less philosophic level, the opposition between the divine and the animal was supported by the popular conceptualization of the Antichrist as the "Beast." With his horns, cloven hoof, long tail and hairy haunches, the "Evil One" was clearly a being in whom the animal nature had gained the upper hand. 
The apotheosis of rationality and the denigration of all those attributes we share in common with other animals, including the emotional and bodily aspects of our existence, has not been a healthy development. It has led on occasion in Christian history to extremes of personal asceticism, as well as to an all-too-ready willingness to sacrifice the bodies of heretics and non-Christians for the sake of their incorporeal souls. Just as feminists have sensitized us to the destructive potential of imaging God in exclusively masculine terms, we must also become awake to the damage wrought by a God-concept that is anthropocentric and which excludes the nonhuman from participation in the Divine Reality, for such a god-made-in-our-own-image is ultimately both oppressive and idolatrous. It is oppressive because, by de-sacralizing the natural world, it encourages us to look upon the earth and its creatures as objects of no intrinsic worth, or as mere means to be exploited for human ends. Destruction of habitat and extinction of species, the misuse of animals in industrial, military, and scientific research, and the victimization of animals in modern factory farming are all symptoms of a theology which has devalued living beings into commodities, while the recent decision to grant a patent to a mouse genetically-engineered to develop cancer (U.S. Patent No. $4,736,866)$ is a frightening portent of things to come. Animal liberation, which at its heart is a call for a shift from an ego-centered to an ecocentered spirituality, also implies human liberation, for it frees us from an idolatrous concept of God. Speciesism, like racism or sexism, is only another form of self-worship in which we attempt to restrict God's care and presence to ourselves and our own kind. It is a way of deliberately blinding ourselves to the fullness of the Divine Reality, whose creative activity is manifest not just among homo sapiens, but in all that lives.

Two hundred years ago, William Wordsworth wrote of the alienation from nature that afflicts the psyche in an urban and materialistic world:

The world is too much with us; late and soon,

Getting and spending, we lay waste our powers:

Little we see in nature that is ours...

We have grown "out of tune" with our organic environment, the poet says, and he repines for a lost "golden age" of antiquity:
Great God! I'd rather be

A Pagan suckled in a creed outworn...

Neither a reversion to pagan religion nor to a romanticized pastoral era seem plausible responses to the ecological and spiritual crises of our times, however. As the Biblical myth of Eden suggests, a return to paradisal harmony between human and non-human is not an option for our race. That vision of primordial community may serve as an ideal, though, in our efforts to bring about a more just and responsible stewardship toward the natural world. We whose religious life springs from Jewish and Christian tradition must learn to respect and revere the animals who, like ourselves, are a part of God's beloved creation, and to cherish the blue green planet that sustains our mutual existence. We must heal the antithesis which pits the divine against the earthy and walk toward a biospirituality that will acknowledge and celebrate the sacred in all of life.

Martin Buber, in his work Israel and Palestine: The History of an Idea, states that "There is a kind of holiness which declares war, as on the profane in general, so in particular on Nature and everything natural as something that must be suppressed in order to attain holiness. But the world, and above all scattered and broken Israel, is in need of Nature. Israel needs the natural life that it has lost; it needs it in order to attain to the true and perfect holiness." As he says elsewhere, "The flaming sword of the cherubim circling the entrance of the Garden of Eden prohibits the way back. But it illumines the way forward."

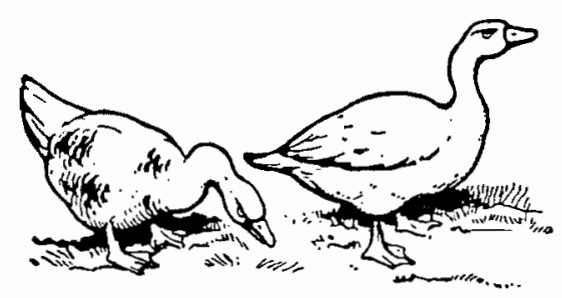

Carol Belanger Grafton, Old-Fashioned Animal Cuts. New York: Dover, 1987 